
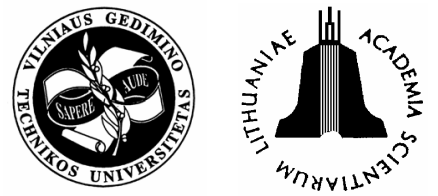

\title{
INFLUENCE OF TECHNOLOGICAL FACTORS ON THE STATE OF STRESS AND STRAIN IN THREE-LAYER REINFORCED CONCRETE STRUCTURES
}

\author{
Linas Juknevičius, Gediminas Marčiukaitis, Juozas Valivonis \\ Dept of Reinforced Concrete and Masonry Structures, Vilnius Gediminas Technical University, \\ Sauletekio al. 11,LT-10233 Vilnius, Lithuania.E-mail: Linas.Juknevicius@st.vtu.lt
}

Received 09 Jan 2006; accepted 15 May 2006

\begin{abstract}
The layered structures are the most efficient building structure elements that distinguish as lightweight and serves for both structural and thermal insulation purposes. The effective performance of all layers is very important condition for the layered structures during its service. The influence of various technological factors on the quality of the layered structures is analysed in this paper. Such technological factors include the quality of the bond between the layers, the composition and processing of the materials used for the layers, different shrinkage strains of the different layers, reinforcement ratio etc. The calculation method and equations for calculating the initial state of stress and strain caused by the concrete shrinkage are presented in the article.
\end{abstract}

Keywords: layered structures, reinforced concrete, elasticity, strength, crack, stress, strain, shrinkage.

\section{Introduction}

Due to the worldwide increase of price of all kinds of fuel - the development of efficient building structure elements that have a low thermal conductivity is one of the most important tasks in nowadays building industry. Moreover, the building codes in many countries constantly introduce higher and higher requirements concerning the thermal insulation properties of the building elements.

According to the thermal insulation requirements in current European building codes - the use of single layer structures is not efficient. All mechanical properties of the material cannot always be utilised while using the single layer structures. For instance, the stress in the middle of the eccentrically compressed or flexural elements is significantly lower than the stress in the edges of the same elements (Fig 1). This example shows that the middle part of the section could be made of materials that have less strength but are significantly cheaper. The purpose of such middle layer is to join the external layers and redistribute stress within the section depth.

When the structure serves for other than thermoinsulating purpose, the internal layers - depending on stress distribution within the section - could be made of weaker and thus cheaper concrete-type materials.

Our analysis has shown that the most popular structures of such a type are the effective hollow slabs which internal layer is made of a cheaper fine aggregate concrete (Fig 2). The high-efficiency structures could be designed using new structural materials. Such structures distinguish as lightweight and have good thermal and humidity insulating properties [1]. The structures consist of two or more layers that are made of different materials. Each layer is designed in the way that most of its best properties could be utilised.

However, the structures of such a type also have some imperfections. Due to the need of the connectors between two external layers - the frost bridges may
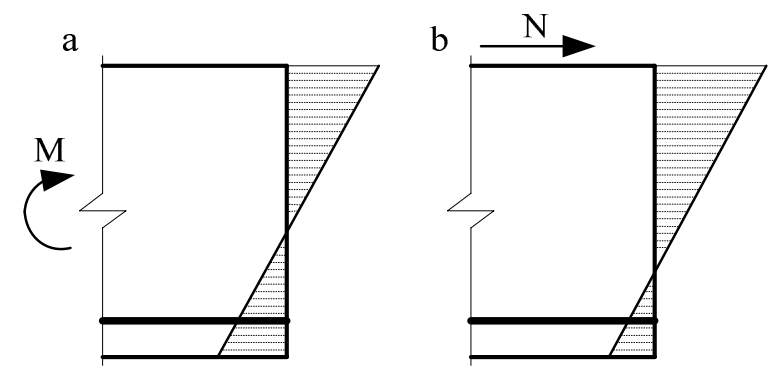

Fig 1. The distribution of the stresses within the depth of the section: $\mathrm{a}$ - flexural elements; $\mathrm{b}$ - eccentrically compressed elements

a

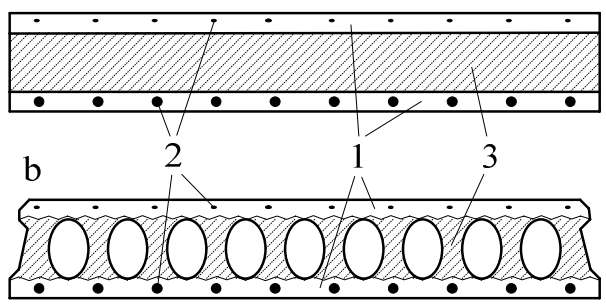

Fig 2. Three-layer structures when layers are made of different concrete-type materials: a) three-layer beam; b) hollow-core floor panel; 1 - external layers made of structural concrete; 2 - longitudinal reinforcement; 3 - internal layers of fine aggregate concrete 
appear in the internal layer. Moreover, the internal layer is usually made manually and therefore the production time and costs increase significantly. There is one more important disadvantage of using other than concrete-type insulating materials - its flammability and the significant decline of thermal insulation properties in case of moisture. Therefore the internal layer in such structures must be additionally protected from fire and moisture. It should be considered that the price and time consumption for the production of such elements increase even more.

Due to the above-mentioned problems, the most popular layered members are three-layer structures with external layers made of reinforced normal concrete, while the internal layer is designed according to the purpose of the structure. One of the greatest advantages of such structures is fast production time. If using only the concrete-type materials for all layers, the production of the layered structure could take single technological cycle, ie casting one layer after another. Such method of production ensures the monolithic bond between the layers. Therefore there is no need to use additional expensive steel elements between the layers: transverse reinforcement, staples, anchors, dispersed reinforcement, etc. The production cost and time consumption for such structures is practically the same if compared to the usual single-layer structures [2].

The internal layer also could be made of the same concrete as the external layers, but in such case the lightweight aggregate (eg polystyrene granules) is used with different fraction. The strength of such concretes is approx 20-30 MPa in the external layers and 3-4 MPa in the internal layer. The densities of the materials are $1100-1400 \mathrm{~kg} / \mathrm{m}^{3}$ and $550-600 \mathrm{~kg} / \mathrm{m}^{3}$ respectively [3].

Three-layer structures with all layers made of concrete-type materials were created in order to solve the problems experienced with layered structures which internal layer is made of mineral wool or polystyrene panels. The main problems were caused by connectors between the external layers, whereas the internal layer made of concrete-type materials ensures a monolithic bond between the layers and in this way ensures the effective performance of all sections and does not require additional steel connectors [4-6].

The consentaneous performance of all layers is the greatest advantage of such type of structures if compared to the usual single-layer structures. Although the effectiveness of the bond between the layers depends on many structural and technological factors, which influence such type of structures and are not sufficiently analysed. This is the main reason that stops a wider application of such structures in building industry. While there is not enough data about the performance of the contact zone between the layers under the loading, the creation of more accurate calculation methods for such type of structures is problematic. Therefore the main aim of this article is the analysis of technological factors and their influence on different shrinkage deformations of the layers and the last-mentioned deformation influence on the overall state of stress and strain in the structure.

\section{The influence of the technological factors on the properties of the interfacial zone between layers}

The consentaneous performance of all layers is very important condition for layered structures during their service. The analyses of sections of layered structures which are made of concrete-type materials have shown that in most cases at least one of the layers is made by casting method. The connectors between the layers usually are stiff. The connectors could be divided into two types: mechanical and physical-chemical.

Mechanical connectors and bond between the layers originate because of pores, capillaries, roughness of the layer surface etc. When the layer surface is even and large, a special roughness and other mechanical connectors have to be made. The absorption belongs to the physical-chemical type of the connectors (bond). It causes the adhesion and cohesion. The strength of the adhesive bond depends on the properties of the interfacial layer surfaces. The thickness of the layers also influences the strength of the adhesive bond. A different thickness causes different values of the internal stresses in layers. The internal stresses appear because of a different strain of the layers due to humidity, temperature and other technological factors. Therefore the compatibility and interdependency of materials is to be checked while designing such structures. Otherwise, the internal stresses exceeding the limit values may occur in a section of the structure.

One of the most important technological factors that influence the strength of the bond between layers is finishing the surface of the previously made layer (the surface which faces a further layer). The surface must be porous, with knobs and caves. The research has shown that the strength of the bond between the layers depends on the shape, size and quantity of the roughness mentioned above. The research has proved that such a bond made of cement mortars or concrete is stronger when the surface knobs and caves have an irregular or conical shape, and is weaker when the surface knobs and caves have a round shape. The strength of bond between the surfaces with different roughness may differ 3-4 times [7, 8]. The surface roughness mainly depends on the production technology. On the other hand, such a bond belongs to chemical and mechanical connectors and therefore depends on both adhesion and the surface roughness. The rougher is the surface, the more dowel-shaped connectors are formed. Moreover, in this case the interfacial surface and the molecular interaction zone are larger.

The bond between cement mortar and concrete layers is strong when the previously made layer is hydrophilic because the layer is moistened well with water and grout. And in this way the air bubble mem- 
branes adsorbed at the surface cracks and pores are eliminated. When previously concreted layer is not hardened during the production process - the mixed chemical and intermixture bond appears between the previously concreted and new layers. In such a case in the contact zone between the layers develops a seam with a unique chemical composition and structure. This phenomenon was also proved by other authors researching the aggregated and cement mortars [9]. The modulus of elasticity of such a seam may be up to 5 times higher if compared to the material properties of the layers itself.

The research carried out by us and other authors has shown that all the above-mentioned technological factors also influence other important factor determining the strength of the bond between layers - the shrinkage deformation of the concrete. When the shrinkage strain is different in the different layers, the internal stresses appear in the contact zone. Such internal stresses may exceed the shear strength of the concrete before the actual loading the layered structure. However, the influence of such internal stresses on the overall performance of the layered structures is not investigated enough.

\section{The influence of technological factors on the concrete shrinkage deformations}

The concrete shrinkage deformations have a significant influence on the internal stresses appearing in the concrete and reinforced concrete structures. According to the opinion of many scientists, a better understanding of the concrete shrinkage mechanism and its factors could be the key to the more accurate evaluation of other processes in the concrete while designing and producing building structures.

The research carried out by us and other authors has shown that the most significant influence on the concrete - as a composite material - shrinkage has the properties of the bonding material - cement stone. The shrinkage deformation of the cement stone is several times higher than the shrinkage of the concrete aggregates. The aggregate shrinkage occurs only after the expansion due to the humidification during production process. The aggregates with zero shrinkage deformations restrain the shrinkage of the cement stone, although concrete aggregates deform elastically due to the cement stone shrinkage. According to the mix law, such a shrinkage process could be described as:

$$
\varepsilon_{s h, c}=V_{c e m} \cdot \varepsilon_{s h, c e m}-V_{a} \cdot\left(\frac{f_{a}-\sigma_{a}}{E_{a}}\right),
$$

here $\varepsilon_{s h, c}, \varepsilon_{s h, c e m}$ - relative shrinkage strain in the concrete and cement stone respectively; $V_{c e m}, V_{a}$ relative volumes of the cement stone and aggregate respectively; $f_{a}, E_{a}$ - compressive strength and the modulus of elasticity of the aggregate; $\sigma_{a}$ - stress in the aggregate caused by cement stone shrinkage.

The analysis of the research carried out by a number of authors has shown that the shrinkage de- formations of concrete stone depend on many factors, such as:

- type of cement, its mineralogical composition and its grind fineness;

- amount of the gypsum (and other mineral salts that melt in the cement-water suspension) in cement;

- water-cement ratio;

- hardening conditions;

- environmental factors (relative humidity, air temperature etc).

The cement stone shrinkage is mainly caused by the migration of the water inside the cement and also by the evaporation of the inter-crystal water [10-12]. The shrinkage mechanisms for concrete and cement stone are different because of their different structures and the development of the last-mentioned. The porosity of the concrete is different if compared to the porosity of the cement stone itself $[10,11]$.

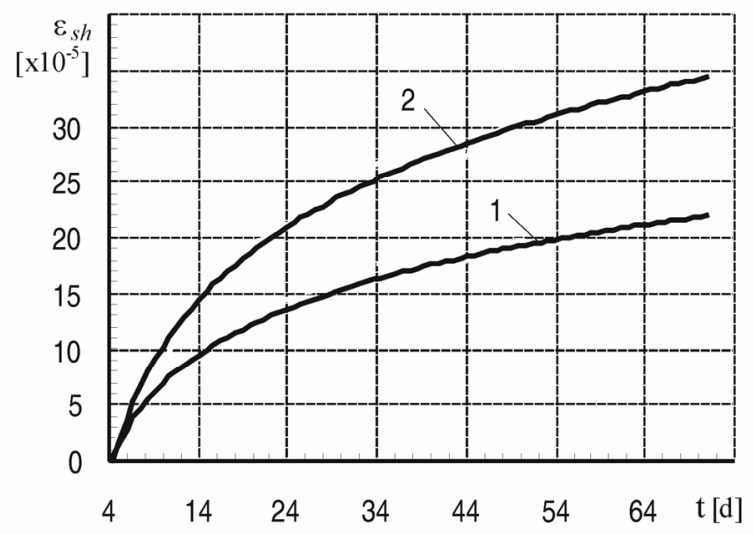

Fig 3. Different unrestrained shrinkage strain of different concrete-type materials: 1 - normal (heavy) concrete; 2 - haydite concrete

According to the Eq (1), the concrete components are not constant values because they depend on the properties of their components. The shrinkage strain of the cement stone $\varepsilon_{\text {sh,cem }}$ depends on many chemical, physical, mechanical and technological factors. The aggregates that do influence the shrinkage and in this way the concrete too - may have a different strength $f_{a}$, modulus of elasticity $E_{a}$ and porosity. It means that the shrinkage strain depends on the aggregate type (Fig 3 ).

The concrete pores and capillaries have a significant influence on the water migration inside the concrete and in this way on the concrete shrinkage [13]. As the strength and modulus of elasticity of the aggregates are significantly higher if compared to the cement stone - their concentration have the main influence on the restraint of the shrinkage strain. Due to the shrinkage strain of the cement stone, the tensile stress takes place inside the cement stone itself and the compressive stress inside the aggregates. The above-mentioned stresses could cause micro-cracks in the cement stone or in the contact zone between the 
cement stone and the aggregate. According to the results of the research carried out by the famous French scientist R. Lermit concerning the influence of various factors (technological ones, too) to the concrete shrinkage - the following expression could be written:

$$
\varepsilon_{s h, c}=\varepsilon_{s h, c e m} \cdot \frac{V_{c}}{V_{c}+\left[1-\left(V_{c}+V+V_{p}+V_{s . a}\right)\right] \cdot k_{a}},
$$

here $V_{c}, V, V_{p}$ - the relative volumes of cement, water and pores respectively; $V_{s . a}$ - the relative volume of the aggregates that are smaller than $0,1 \mathrm{~mm}$; $k_{a}$ - factor describing the compressive strength of the aggregates.

The analysis of the equations above has shown that despite the identical cement the concrete shrinkage strain depends on many other technological factors [14-17]. All factors shown in the Eq (2) and their values influence the concrete shrinkage strain. Even a small deviation (from optimal values) of these factors has a larger influence on concrete shrinkage strain if compared to the concrete strength [18].

The structure of the concrete and its porosity depends not only on the proportions of the mix but also on many technological factors. According to the research results, the strength of the concrete is 17-30\% higher and the shrinkage is $10-15 \%$ lower if it is mixed with the forced concrete-mixer, if compared to the concrete of the same mix composition but mixed in a gravity concrete-mixer [19].

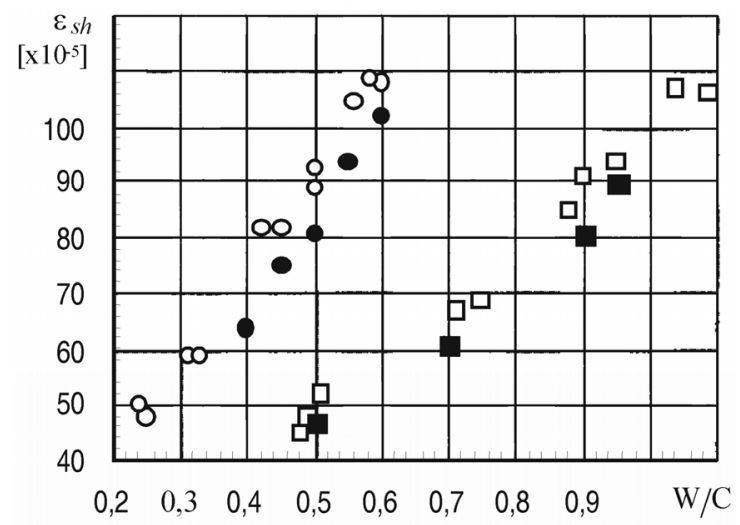

Fig 4. The dependence of the shrinkage strain of the concrete prisms during 120 days (outdoors) on the water and cement ratio W/C and the amount of cement: - $-600 \mathrm{~kg} / \mathrm{m}^{3} ;-300 \mathrm{~kg} / \mathrm{m}^{3}$ (experiments carried out by authors); ○ $-700 \mathrm{~kg} / \mathrm{m}^{3}$; 口 - $350 \mathrm{~kg} / \mathrm{m}^{3}$ [20]

All the concrete properties also depend on the mixing period $[21,22]$. The porosity of the concrete (having a significant influence on the shrinkage strain) also depends on the quality and manner of concrete mixing, especially on its compaction. The research carried out by us and other authors has shown that, depending on the compaction, the porosity of the concrete may vary considerably. For instance, the porosity of the normal heavy concrete with sand and gravel aggregates, when water and cement ratio is $\mathrm{W} / \mathrm{C}=0,4$ and the amount of cement is $\mathrm{C}=320 \mathrm{~kg} / \mathrm{m}^{3}$ - may vary from 30 to $23 \%$. The analysis of Eq (2) has shown that the total amount of water and cement together with the $\mathrm{W} / \mathrm{C}$ ratio has the main influence on the concrete shrinkage deformations. That proves the experimental data presented in Fig 4. The W/C ratio also changes the actual influence of other technological factors: mixing, compaction etc.

\section{The reinforcement influence on the state of stress and strain}

The shrinkage effect is the time dependent phenomena. The creep effect also is to be considered when calculating the deformations of flexural members subjected to a long-term loading. Although most of the practical calculation methods use static (usually - ultimate) deformation values for estimating the above-mentioned effects. This paper also deals with static values in order to simplify the calculation formulas. It is assumed that these static values are obtained by estimating all possible influencing factors like time, creep, surface area, relative humidity, both drying and autogenous shrinkage etc.

The external layers are usually reinforced while designing the layered structures made of concretetype materials. The bond between the steel reinforcement and the concrete is stiff and therefore such a bond is acting as the internal connector that restrains the concrete shrinkage. Thus the shrinkage of reinforced concrete is restrained. The research has shown that the shrinkage strain of the reinforced concrete is two or more times less than the shrinkage strain of the unrestrained (plain) concrete. The actual shrinkage strain of the reinforced concrete depends on the amount of reinforcement (reinforcement ratio). The concrete shrinkage strain causes the internal tensile stresses in the concrete and the internal compressive stresses in the reinforcement [23]. The compressive and tensile stresses are in equilibrium, thus the following equation could be written:

$$
\sigma_{s} \cdot A_{s}=\sigma_{c t} \cdot A_{c},
$$

here $\sigma_{s}, \sigma_{c t}-$ the compressive stress in reinforcement and tensile stress in concrete (respectively); $A_{s}$, $A_{c}$ - the cross-section areas of reinforcement and concrete respectively.

The reinforcement resists to the concrete unrestrained shrinkage strain $\left(\varepsilon_{s h, 0}\right)$ and therefore the actual shrinkage strain is smaller $\left(\varepsilon_{s h, 1}\right)$. The difference between the above-mentioned strains represents the tensile strain in the concrete:

$$
\varepsilon_{c t}=\varepsilon_{s h, 0}-\varepsilon_{s h, 1} .
$$

When the unrestrained shrinkage strain of the concrete is known - the Eqs (3) and (4) and the scheme in Fig 5 could be used to determine the mean compressive strain in the reinforcement: 


$$
\varepsilon_{s h, I, i}=\frac{\varepsilon_{s h, 0, i}}{1+\alpha_{i} \cdot \rho_{i}},
$$

here $\varepsilon_{s h, I, i}, \varepsilon_{s h, 0, i}$ - the restrained and unrestrained (respectively) shrinkage strains of the concrete of the $i^{\text {th }}$ layer.
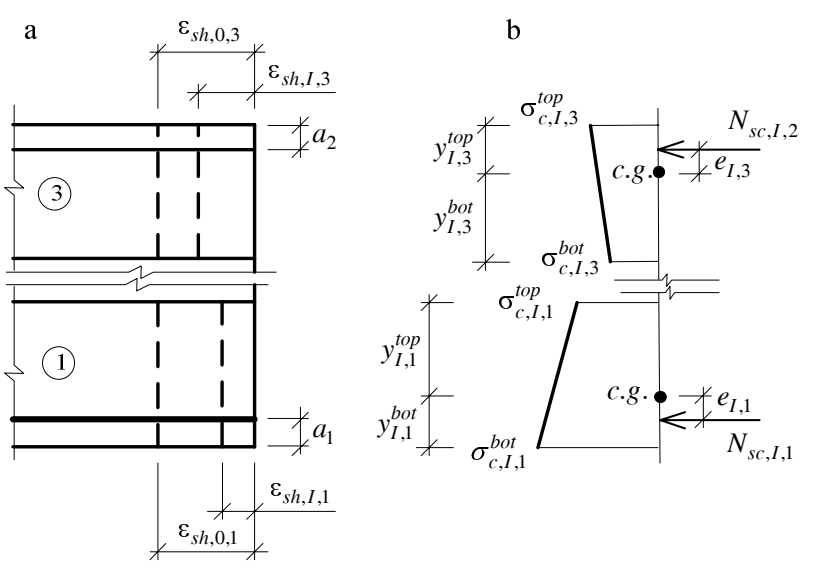

Fig 5. The state of stress and strain in the external layers of three-layered member due to the concrete shrinkage: $\mathrm{a}$ - strain distribution; $\mathrm{b}$ - stress distribution

The mean compressive stress in the $n^{\text {th }}$ reinforcement (in the $i^{\text {th }}$ layer) could be calculated using the following equation:

$$
\sigma_{s c, I, n}=\varepsilon_{s h, I, i} \cdot E_{s, n}=\frac{\varepsilon_{s h, 0, i} \cdot E_{s, n}}{1+\alpha_{i} \cdot \rho_{i}},
$$

here $\alpha_{i}=\frac{E_{s, n}}{E_{c, i} \cdot v_{i}} ; \rho_{i}=\frac{A_{s, n}}{A_{c, i}} ; E_{s, n}, E_{c, i}-$ the initial modulus of elasticity of $n^{\text {th }}$ reinforcement and the concrete in the $i^{\text {th }}$ layer respectively; $A_{s, n}, A_{c, i}$ - the cross-section area of $n^{\text {th }}$ reinforcement and the concrete in the $i^{\text {th }}$ layer respectively; $v_{i}$ - the coefficient of elasticity of the concrete in the $i^{\text {th }}$ layer (for normal strength concrete $v$ could differ from 0,3 to 0,55 ).

As it is shown in Fig 5 - the tensile stresses in concrete are not equal in different layers when the structure is reinforced asymmetrically. The normal stresses in the concrete of the external layers are greater at the layer edge that is closer to the centre of gravity of reinforcement bars. Therefore the stresses in the bottom layer will be greater at the layer bottom edge and the stresses in the top layer will be greater at the layer top edge (Fig 5):

$$
\sigma_{c, I, i}=\frac{N_{s c, I, n}}{A_{e f f, i}} \pm \frac{M_{I, i} \cdot y_{I, i}}{I_{e f f, i}},
$$

here $N_{s c, I, n}$ - the resultant compressive axial force in the $n^{\text {th }}$ reinforcement; $y_{I, i}-$ the distance from the edge of the $i^{\text {th }}$ layer to its centre of gravity; $M_{I, i}-$ the flexural moment in the $i^{\text {th }}$ layer caused by the eccentricity of the acting axial force; $I_{\text {eff }, i}-$ the moment of inertia of the effective cross-section of the $i^{\text {th }}$ layer;
$A_{e f f, i}-$ the area of the effective cross-section of the $i^{\text {th }}$ layer.

The position of the centre of gravity of the effective cross-section may be found using the known material mechanics formulas and taking into account the geometrical and mechanical characteristics of the concrete.

Having the shrinkage strains of all the layers (taking into account the influence of reinforcement on the external layers) - the analogical equations could be used to determine the stresses that may appear because of the different shrinkage strains of the layers. According to the Eq (2), the shrinkage strain of the reinforced layers is greater if compared to the plain concrete. Eq (2) also shows that even in case of the use of the same concrete (having the same unrestrained shrinkage strain) for all the layers - the shrinkage strains of the external layers will differ from the shrinkage strains of the internal layer. The shrinkage strain of the external layer will be smaller because of the influence of steel reinforcement. Moreover, the internal layer is usually made of the lightweight concrete-type materials which unrestrained shrinkage deformations are greater if compared to the normal concrete used for external layers. Therefore the additional tensile stress will appear in the concrete of internal layer and accordingly the additional compressive stresses will appear in both concrete and reinforcement of the external layers.

\section{The state of stress and strain within the section of layered member}

The design scheme of the three-layer member could be changed to effective design scheme, while the strains of the external layers are equalised to zero and the strains in both top and bottom edges of the internal layer are changed according to the difference between the shrinkage strains of the internal layer and its neighbouring layer (Fig 6, a).

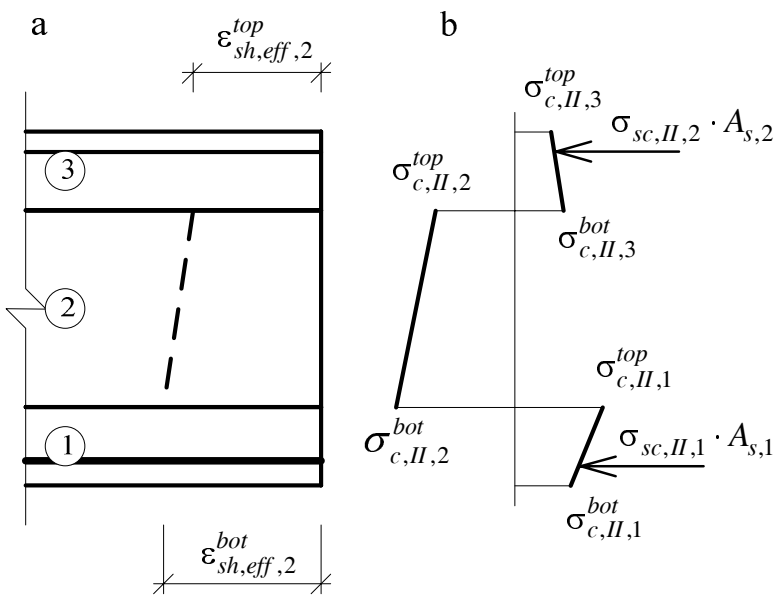

Fig 6. The state of stress and strain in cross-section of the three-layer member caused by different shrinkage strains of the layers: a - effective distribution of strains; $b$ - effective distribution of stresses 
Due to the use of lightweight concrete-type materials the unrestrained shrinkage strain of the internal layer is greater if compared to the external layers (especially taking into account the reinforcement resistance to concrete shrinkage). Therefore the effective strains in the top and bottom edges of the internal layer could be expressed as follows (Fig 6):

$$
\begin{aligned}
& \varepsilon_{s h, e f f, 2}^{\text {bot }}=\varepsilon_{s h, 0,2}-\varepsilon_{s h, I, 1} ; \\
& \varepsilon_{s h, e f f, 2}^{t o p}=\varepsilon_{s h, 0,2}-\varepsilon_{s h, I, 3},
\end{aligned}
$$

here $\varepsilon_{s h, e f f, 2}^{b o t}, \varepsilon_{s h, e f f, 2}^{t o p}-$ the effective shrinkage strains at the bottom and top edges (respectively) of the internal layer; $\varepsilon_{s h, 0,2}$ - the unrestrained shrinkage strain of the internal layer; $\varepsilon_{s h, I, 1}, \varepsilon_{s h, I, 3}$ - the restrained shrinkage strains of the bottom and top external layers respectively.

The normal stresses caused by the strain difference between neighbouring layers could be calculated using the equations given for calculating of the stresses in the external layers (caused by reinforcement resistance to concrete shrinkage). Although in this case the all cross-section of three-layer member should be transformed into effective cross-section. Such transformation could be done according to the modulus of elasticity of the internal layer. The external layers in such case are treated as external compressive reinforcement [20]. Also, the assumption that a half of the internal layer is affecting one external layer and the other half is affecting other (neighboring) external layer is taken into account.

Then the normal tensile stresses in both edges of the internal layer and the resultant tensile axial force could be determined according to the effective strains. The mean tensile strains in the edges of the internal layer caused by the resistance of external neighbouring layers to the shrinkage deformation of the internal layer - could be calculated by following equation:

$$
\varepsilon_{s h, I I, 2}^{m}=\frac{\varepsilon_{s h, e f f, 2}^{m} \cdot \alpha_{e f f, i} \cdot \kappa_{e f f, i}}{1+\alpha_{e f f, i} \cdot \kappa_{e f f, i}} .
$$

Then the normal tensile stresses in the edges of the internal layer could be calculated according to the Hooke's law and taking into account the coefficient of elasticity of tensile concrete $\left(v_{i}\right)$ :

$$
\sigma_{c, I I, 2}^{m}=\varepsilon_{s h, e f f, 2}^{m} \cdot E_{c, 2} \cdot v_{2}=\frac{\varepsilon_{s h, e f f, 2}^{m} \cdot E_{c, i} \cdot \kappa_{e f f, i}}{1+\alpha_{e f f, i} \cdot \kappa_{e f f, i}},
$$

here $\quad \alpha_{e f f, i}=\frac{E_{c, i}}{E_{c, 2} \cdot v_{2}} ; \quad \kappa_{e f f, i}=\frac{2 \cdot A_{e f f, i}}{A_{c, 2}} ; \quad m=$ bot , when calculating the mean tensile stress at the bottom egde of the internal layer and $m=t o p$, when calculating the mean tensile stress at the top edge of the internal layer; $i=1$, when $m=$ bot and $i=3$, when $m=t o p$.

The stresses in different edges of the internal layer could also be different due to a different amount of reinforcement in the external layers. The difference between the strains in the neighbouring layers and in this way the tensile stress in the internal layer will be greater in the edge of the internal layer that faces the external layer containing the main reinforcement.

When the stresses on the both edges of internal layer are known - two resultant axial forces could represent them. Each of these axial forces affects one external layer. According to the principle of force superposition - it could be said that the internal layer will affect external layer through the contact zone between the layers and therefore the position of axial forces in the cross-section will coincide with the position of the contact zone (Fig 7).

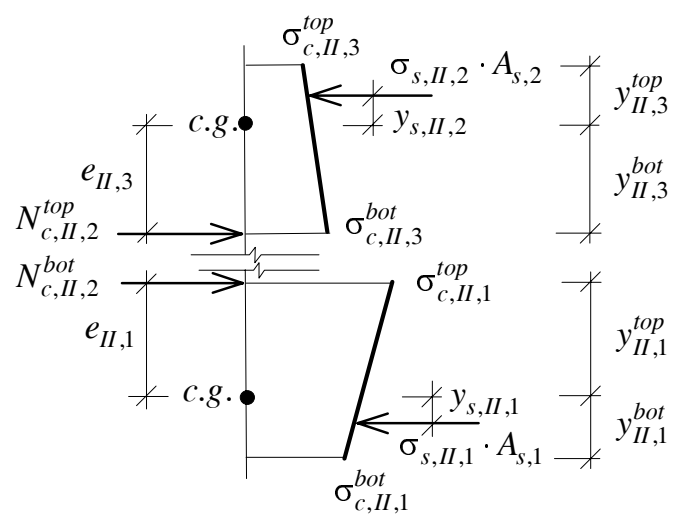

Fig 7. The distribution of the stresses in the external layers caused by the greater shrinkage strain in the internal layer

According to the assumption that one half of the internal layer is affecting one external layer and the other one is affecting other external layer - the resultant axial forces acting in the external layers could be calculated:

$$
\begin{aligned}
& N_{c, I I, 2}^{b o t}=\frac{\left(2 \cdot \sigma_{c, I I, 2}^{b o t}+\sigma_{c, I I, 2}^{t o p}\right)}{8} \cdot t_{2} \cdot b_{2} ; \\
& N_{c, I I, 2}^{t o p}=\frac{\left(2 \cdot \sigma_{c, I I, 2}^{t o p}+\sigma_{c, I I, 2}^{b o t}\right)}{8} \cdot t_{2} \cdot b_{2},
\end{aligned}
$$

here $N_{c, I I, 2}^{b o t}, N_{c, I I, 2}^{t o p}-$ the resultant axial forces acting in the bottom and top edges (respectively) of the internal layer (Fig 7); $t_{2}$ - the thickness of the internal layer; $b_{2}-$ the width of the internal layer; $\sigma_{c, I I, 2}^{b o t}$, $\sigma_{c, I I, 2}^{t o p}-$ the tensile stresses in the bottom and top edges (respectively) of the internal layer (Eq 11).

The resultant tensile axial force acting in the internal layer is equal to the sum of the resultant compressive axial forces acting in the external layers. And due to the fact that the resultant compressive axial forces in external layers are acting with eccentricity the bending moment appears in the external layer.

The position of the resultant compressive axial forces acting in the external layer coincides with the position of the respective external layer edge neighbouring with the internal layer. Therefore the 
eccentricity, ie the distance from the position of resultant axial forces acting in external layer to the centre of gravity of the external layers could be obtained as follows (Fig 7):

$$
\begin{aligned}
& e_{I I, 1}=y_{I I, 1}^{t o p} ; \\
& e_{I I, 3}=y_{I I, 3}^{b o t},
\end{aligned}
$$

here $e_{I I, 1}, e_{I I, 3}-$ the eccentricities of the axial forces acting in the external layers (bottom and top respectively); $y_{I I, 1}^{t o p}, y_{I I, 3}^{b o t}-$ the distances from the centre of gravity of bottom and top (respectively) external layer to the closest edge of the internal layer.

The resultant compressive axial forces are acting on both concrete and reinforcement of the external layer. Therefore the distance between the two centres of gravity (the effective section of the layer and reinforcement) could be calculated as follows:

$$
\begin{aligned}
& y_{s, I I, 1}=y_{I I, 1}^{b o t}-a_{1} ; \\
& y_{s, I I, 2}=y_{I I, 3}^{t o p}-a_{2},
\end{aligned}
$$

here $y_{I I, 1}^{b o t}, y_{I I, 3}^{t o p}-$ the distances from the centres of gravity of external layers to the bottom and top (respectively) edges of these layers; $a_{1}, a_{2}$ - the distances from the centres of gravity of tensile and compressive reinforcement to the external edge of the structure (respectively).

When the acting axial forces and the eccentricities are known, the additional bending moments acting in the external layers could be calculated:

$$
\begin{aligned}
& M_{I I, 1}=N_{c, I I, 2}^{b o t} \cdot e_{I I, 1} ; \\
& M_{I I, 3}=N_{c, I I, 2}^{t o p} \cdot e_{I I, 3},
\end{aligned}
$$

here $M_{I I, 1}, M_{I I, 3}$ - the additional bending moments acting in the bottom and top (respectively) external layers.

Then the design scheme shown in Fig 7 could be used and the following equation for the calculation of the additional normal stresses acting in the edges of external layers could be written:

$$
\sigma_{c, I I, i}^{m}=\frac{N_{c, I I, 2}^{m}}{A_{e f f, i}} \pm \frac{M_{I I, 1} \cdot y_{I I, i}^{m}}{I_{e f f, i}} .
$$

The additional normal stresses in the reinforcement could be obtained by using the linear $\sigma-\varepsilon$ relationship and the assumption that the strain in the reinforcement of the reinforced concrete members is equal to the strain of the concrete at the reinforcement. Therefore the equation for calculating the additional stress in the reinforcement could be written as follows:

$$
\begin{aligned}
& \sigma_{s, I I, n}=\varepsilon_{s, I I, n} \cdot E_{s, n}=\sigma_{c, I I, i}^{s, n} \cdot \frac{E_{s, n}}{E_{c, i}}= \\
& =\left(\frac{N_{c, I I, 2}^{n}}{A_{e f f, i}} \pm \frac{M_{I I, i} \cdot y_{s, I I, n}}{I_{e f f, i}}\right) \cdot \frac{E_{s, n}}{E_{c, i}}
\end{aligned},
$$

here $\sigma_{c, I I, i}^{s, n}$ - the normal stress in the concrete at the $n^{\text {th }}$ reinforcement in the $i^{\text {th }}$ layer; $n=1$ for the tensile and $n=2$ for compressive reinforcement.

\section{The total stresses in the cross-section and its influence on the layer cracking}

The total initial normal stresses acting in the three-layer cross-section consist of the stresses caused by the reinforcement resistance to concrete shrinkage in the external layers and the stresses caused by the different shrinkage strains of different layers and the stiff bond between the neighbouring layers.

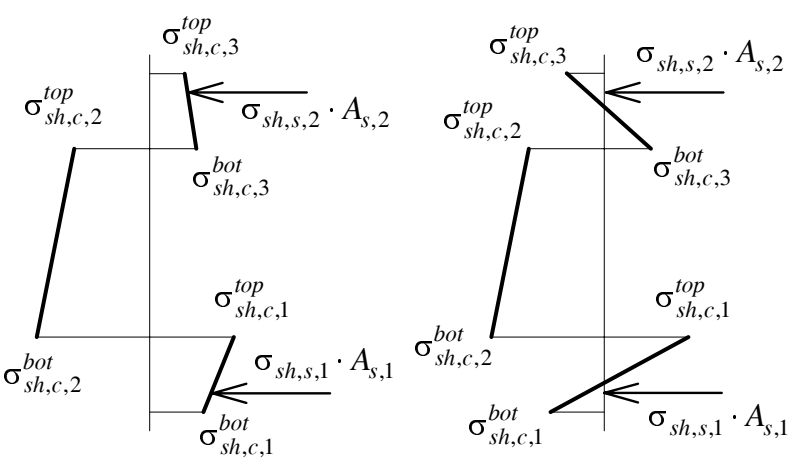

Fig 8. The state of stress and strain in the all threelayer cross-section caused by different shrinkage strains in different layers: $\mathrm{a}-$ the case when all section of external layer is compressed; $b$ - the case when external part of external layer is tensile

Therefore the total stresses in the external layers could be calculated (Fig 8):

$$
\sigma_{s h, c, i}^{m}=\sigma_{c, I I, i}^{m}-\sigma_{c, I, i}^{m},
$$

here $\sigma_{c, I, i}^{m}$ - the normal stress in the concrete of $i^{\text {th }}$ external layer and caused by the resistance of the reinforcement to the concrete shrinkage deformations $(\mathrm{Eq} 7) ; \sigma_{c, I I, i}^{m}-$ the normal stress in the concrete of $i^{\text {th }}$ external layer and caused by the different shrinkage deformations in neighbouring layers (Eq 20).

The total tensile stresses in the internal layer are equal to the stresses caused by different shrinkage strains of different layers:

$$
\sigma_{s h, c, 2}^{m}=\sigma_{c, I I, 2}^{m},
$$

here $\sigma_{c, I I, 2}^{m}$ - the tensile stress in the concrete of internal layer and caused by the different shrinkage deformations in neighbouring layers (Eq 11).

The total compressive stresses in the reinforcement of external layer could be calculated as follows:

$$
\sigma_{s h, s, n}=\sigma_{s c, I, n}+\sigma_{s, I I, n},
$$

here $\sigma_{s c, I, n}$ - the compressive stress in the $n^{\text {th }}$ reinforcement and caused by its resistance to the concrete 
shrinkage deformations (Eq 6); $\sigma_{s c, I I, n}$ - the compressive stress in the $n^{\text {th }}$ reinforcement and caused by the different concrete shrinkage deformations in neighbouring layers (Eq 21).

The estimation of the stress acting direction is very important while using the equations given above. Depending on the actual mechanical and geometrical properties of the cross-section, the component stresses could act in the same or in the opposite directions. When the component stresses are acting in the same direction - they have to be summarised. Although when the stresses are acting in different directions, they have to be subtracted and the stress that has a greater value will determine the final acting direction for resultant total stress. The internal layer will always be tensioned and therefore the external layer edges facing the internal layer will always be compressed. The reinforcement in the external layers will also be compressed in all cases. Although the external edges of the external layers could be both compressed or tensioned (Fig 8). Eq (23) shows that the final direction of the stresses acting in the external parts of the external layers depends on the stresses caused by reinforcement resistance and the stresses caused by different strains of the different layers.

The total initial stresses should be taken into account when calculating the bearing capacity and the cracking moment of the three-layered structures. Thus the initial stresses in concrete and reinforcement have to be summarised with the stresses at the same point of cross-section and which are caused by the flexural moment. Also the directions of the initial stresses and stresses caused by flexural moment have to be taken into account, because these directions could be both coincident and opposite.

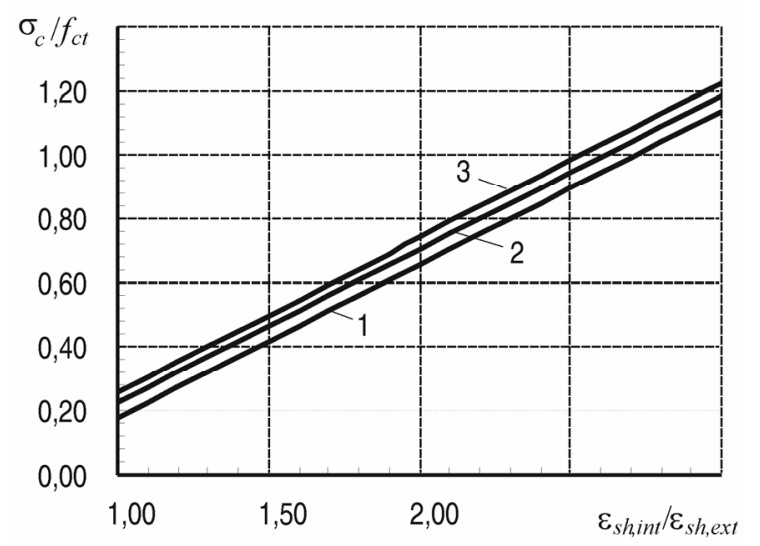

Fig 9. The relationship between the tensile stress in the bottom edge of the internal layer and the shrinkage strain ratio between neighbouring layers and the reinforcement ratio of the external layer $\rho_{\text {ext }}: 1-4 \%$; $2-6 \% ; 3-8 \%$

The estimation of the initial stresses caused by concrete shrinkage is very important because in some cases the initial stress values could exceed the limit tensile stress values of the concrete used for internal layer. In such cases the cracks will occur in the layer before the actual loading of the three-layer structure. Therefore the initial state of stress and strain must be considered while designing such type of structures.

The diagrams presented in Fig 9 show that the cracks in the external bottom layer may appear due to the reinforcement resistance to the concrete shrinkage and when the difference between the strains of the external and internal layers is greater than 2,5 times. Although when such a difference is 1,5 times - the stresses in the concrete reaches approx $50 \%$ of its tensile strength. Therefore the cracks in the concrete may appear under relatively small external bending moment.

The analysis of the diagrams presented in Fig 10 shows that the ratio between the strains of the layer materials has a more significant influence on the initial stress values if compared to the values of shrinkage strains itself.

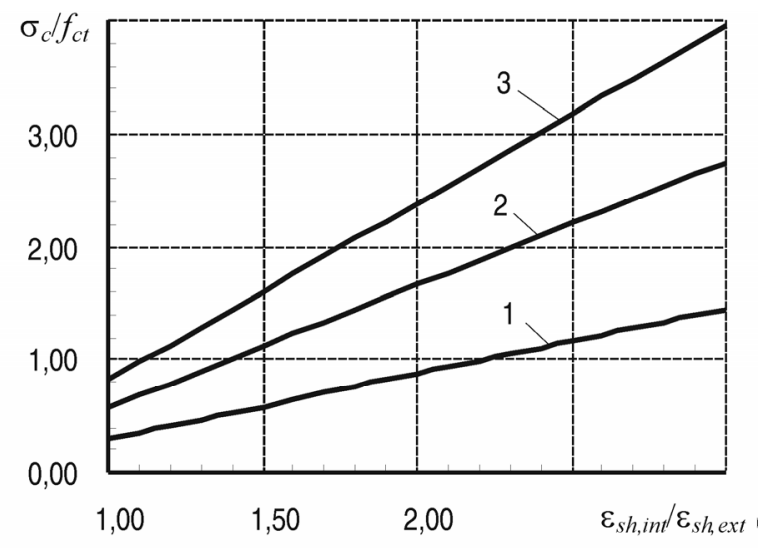

Fig 10. The relationship between the tensile stress in the bottom edge of the internal layer, the shrinkage strain ratio and the modulus of elasticity ratio $E_{c, \text { int }} / E_{c, \text { ext }}$ between neighbouring layers: $1-0,1$; $2-0,2 ; 3-0,3$

The tensile stress in the concrete of the external layers in some cases may exceed the limit values even several times. Then the cracks will appear in the external layers and their width may exceed the limit values.

\section{Conclusions}

1. The initial state of stress and strain caused by the different shrinkage strains of different layers should be considered while designing and producing the layered structures made of concrete-type materials.

2. The analysis has shown that the shrinkage strain of the concrete and the consentaneous performance of all layers depend on various technological factors. The provided equations allow the adjustment of these factors according to their influence on the shrinkage strain.

3. The analysis of the development of both unrestrained and restrained shrinkage strains in different 
concrete layers allows the creation of the estimation method for the consentaneous deformation model of the connected layers.

4. The calculation method and equations for the calculation of the initial state of stress and strain caused by the concrete shrinkage are presented in the article.

The given calculation method allows a more accurate estimation of the cracking of the layers under an external loading.

\section{References}

1. Meškauskas, J. Reinforced haydite concrete structures (Керамзитожелезобетонные конструкции). Vilnius, 1984. 194 p. (in Russian).

2. Korol, E. A. Three-layer enclosure structures made of reinforced lightweight concrete and the peculiarities of their calculation. Monograph (Трехслойные ограждающие железобетонные конструкции из легких бетонов и особенности их расчета. Монография). Moscow: ACB, 2001. 256 p. (in Russian).

3. Neville, A. M. Properties of concrete. 4th ed. Longman Scientific \& Technical, England, 1997. 844 p.

4. Mouritz, A. P.; Thompson, R. S. Compression, flexure and shear properties of a sandwich composite containing defects. Composite Structures, 44(4), 1999, p. 263-278.

5. Marčiukaitis, G., Juknevičius, L. Influence of the internal layer cracks on the cracking of flexural threelayer concrete members. Journal of Civil Engineering and Management, VIII(3), 2002, p. 153-158.

6. Marčiukaitis, G.; Bistrickaite, R. Structural-technological factors of efficiency of floors with permanent reinforced concrete formwork. Technological and Economic Development of Economy, XI(2), 2005, p. 87-94 (in Lithuanian).

7. Rac, G. A.; Prasad, B. K. B. Influence of the roughness of aggregate surface on the interface bond strength. Cement and Concrete Research, 32(2), 2002, p. 253-257.

8. Bentz, D. P.; Garboczi, E. J. Simulation studies of effects of mineral admixtures on the cement pasteaggregate interfacial zone. ACI Material Journal, 88(5), 1991, p. 518-529.

9. Breton, D.; Ballivy, J.; Grandet, J. Contribution to the formation mechanism of the transition zone between rock-cement pastes. Cement and Concrete Research, 23, 1993, p. 335-346.

10. Achverdov, I. N. Basics of concrete physics (Основы физики бетона). Moscow: Stroiizdat, 1981. 463 p. (in Russian).
11. Sheikin, A. E. Structure, strength and crack resistance of the cement stone (Структура, прочность и трещиностойкость цементного камня). Moscow: Stroiizdat, 1974. 191 p. (in Russian).

12. Lermit, R. Concrete technology problems (Проблемы технологии бетона). Moscow: Stroiizdat, 1959. 294 p. (in Russian).

13. Kearsley, E. P.; Wainwright, P. J. The effect of porosity on the strength of foamed concrete. Cement and Concrete Research, 32(2), 2002, p. 233-239.

14. Kohno, K.; Okamoto, T.; Isikawa, Y.; Sibata, T.; Mori, $\mathrm{H}$. Effects of artificial lightweight aggregate on autogenous shrinkage of concrete. Cement and Concrete Research, 29(4), 1999, p. 611-614.

15. Lura, P.; Van Breugel, K.; Maruyama, I. Effect of curing temperature and type of cement on early-age shrinkage of high-performance concrete. Cement and Concrete Research, 31(12), 2001, p. 1867-1872.

16. Persson, B. Eight-year exploration of shrinkage in high-performance concrete. Cement and Concrete Research, 32(8), 2002, p. 1229-1237.

17. Folliard, K. J.; Berke, N. S. Properties of highperformance concrete containing shrinkage-reducing admixture. Cement and Concrete Research, 27(9), 1997, p. 1357-1364.

18. Marčiukaitis, G. Construction of monolithic concrete and reinforced concrete structures. Materials, Technology, Quality (Monolitinių betoninių ir gelžbetoninių konstrukcijų statyba. Medžiagos, technologija, kokybė). Vilnius: Technika, 1999. 203 p. (in Lithuanian).

19. Desov, A. E. Technology and properties of heavy concretes (Технология и свойства тяжелых бетонов). Moscow: Stroiizdat, 1971. 205 p. (in Russian).

20. Michailov, V. V. Pre-tensioned reinforced concrete structures (Предварительно напряженные железобетонные конструкции). Moscow: Stroiizdat, 1978. 383 p. (in Russian).

21. Laukaitis, A. The properties of porous concrete mixes and their products. Monograph (Akytujų betonų formavimo mišinių ir jų gaminių savybès. Monografija). Vilnius: Technika, 2000. 232 p. (in Lithuanian).

22. Park, S. B.; Yoon, E. S.; Lee, B. I. Effects of processing and materials variations on mechanical properties of lightweight cement composites. Cement and Concrete Research, 29(2), 1999, p. 193-200.

23. Marčiukaitis, G. Shrinkage influence on stress-strain state of composite masonry structures. Statyba (Civil Engineering), VII(3). Vilnius: Technika, 2001, p. $177-183$.

\section{TECHNOLOGINIŲ VEIKSNIŲ ITAKA TRISLUOKSNIŲ GELŽBETONINIŲ ELEMENTŲ ITEMPIỤ IR DEFORMACIJŲ BŪVIUI}

\section{Juknevičius, G. Marčiukaitis, J. Valivonis}

Santrauka

Sluoksniuotosios konstrukcijos yra efektyviausi statinių elementai, kurie yra lengvi ir atlieka ir konstrukcinę, ir termoizoliacinę funkcijas. Bendras visų sluoksnių darbas yra labai svarbi sąlyga eksploatuojant sluoksniuotąsias konstrukcijas. Straipsnyje analizuojama įvairių technologinių veiksnių įtaka sluoksniuotụjų konstrukcijų kokybei. 
Analizuojami tokie technologiniai veiksniai kaip sukibimo tarp sluoksnių kokybė, sluoksniams pagaminti naudojamų mišinių sudètis ir jų gamybos ypatumai, skirtingos sluoksnių betonų susitraukimo deformacijos, armavimo koeficientas ir t. t. Straipsnyje pateikta skaičiavimo metodika ir formulès leidžia ịvertinti pradini ịtempių ir deformacijų būvị, atsiradusị dèl betono susitraukimo.

Reikšminiai žodžiai: sluoksniuotosios konstrukcijos, stiprumas, plyšys, įtempiai, deformacijos, susitraukimas.

Linas JUKNEVIČIUS. Assistant, Dept of Reinforced Concrete and Masonry Structures. Vilnius Gediminas Technical University (VGTU), Sauletekio al. 11, LT-10223 Vilnius, Lithuania.

E-mail: Linas.Juknevicius@st.vtu.lt

BSc (1997) and MSc (1999) in Civil Engineering at Vilnius Gediminas Technical University. Author of 4 scientific articles. Research interests: mechanics of reinforced layered structures made from concrete-type materials.

Gediminas MARČIUKAITIS. Professor, Doctor Habil, Dept of Reinforced Concrete and Masonry Structures. Vilnius Gediminas Technical University (VGTU), Sauletekio al. 11, LT-10223 Vilnius, Lithuania. E-mail: gelz@st.vtu.lt

PhD (Kaunas Politechnical Institute, 1963). Research visit to the University of Illinois (1969). Doctor Habil (1980) at Moscow Civil Engineering University, Professor (1982). Author and co-author of 5 monographs, 6 textbooks and more than 300 scientific articles. Research interests: mechanics of reinforced concrete, masonry and layered structures, new composite materials, investigation and renovation of buildings.

Juozas VALIVONIS. Doctor, Associate Professor, Dept of Reinforced Concrete and Masonry Structures. Vilnius Gediminas Technical University (VGTU), Saulètekio al. 11, LT-10223 Vilnius, Lithuania. E-mail: gelz@st.vtu.lt

Doctor (1986). Author of over 50 publications, 2 patented inventions. Research interests: theory of reinforced concrete behaviour, composite structures, reinforced concrete bridges. 